\title{
La construcción jurisprudencial de la propia imagen constitucional*
}

\author{
Esperanza Gómez Corona \\ Profesora Contratada Doctora de Derecho Constitucional \\ Universidad de Sevilla
}

Recibido: 21.06.2010

Aceptado: 30.06 .2010

Resumen: En este trabajo se analiza la configuración constitucional del derecho fundamental a la propia imagen a partir de la jurisprudencia del Tribunal Constitucional. La ausencia de antecedentes en nuestro país, así como la falta de referentes en el Derecho Comparado, hace imprescindible acudir a la jurisprudencia del Tribunal Constitucional. Al efecto, se analiza la definición constitucional del derecho, su relación con otros derechos de la personalidad, su objeto y sus límites. Se analiza además la actividad del derecho como límite de la actividad de los medios de comunicación, distinguiendo entre la actividad de información y la prensa de entretenimiento. Asimismo, se analiza el derecho a la propia imagen como límite en el ámbito de las relaciones laborales. El estudio permite conocer la configuración constitucional del derecho a la propia imagen que el Tribunal Constitucional ha venido realizando en su jurisprudencia.

Palabras clave: derecho fundamental a la propia imagen, libertad de información, jurisprudencia constitucional.

Abstract: The aim of this paper is to carry out a thorough analysis of constitutional case-law related to the right to one's own image. The absence of constitutional antecedents and the lack of regulation in Comparative Law, make this approach essential. The constitutional configuration of this fundamental right, its connections to other rights, its object and limits are studied. The role of the right to one's own image as a limit of the activities of mass medias is also considered, as well as the role of this right in the labour relations. This study may contribute to the knowledge of the constitutional configuration of this fundamental right.

Key words: dight to one's own image, freedom of the press, constitutional jurisprudence.

Sumario: 1. I. Planteamiento.-II. La configuración constitucional del derecho a la propia imagen en la jurisprudencia del Tribunal Constitucional.- - III. El derecho a la propia imagen en el ámbito de las relaciones laborales. III.1. El derecho a configurar la imagen propia. III.2. El

* Este trabajo ha sido elaborado en el marco de una investigación financiada por el Ministerio de Ciencia e Innovación, a través del Programa Nacional de Movilidad de Recursos Humanos del Plan Nacional de I+D+i 2008-2011. 
derecho a la propia imagen como límite en las relaciones contractuales.IV. El derecho a la propia imagen como límite de la actividad de los medios de comunicación. IV.1. Propia imagen y prensa de entretenimiento. IV. 2. Propia imagen y libertad de información.

\section{Planteamiento}

La constitucionalización expresa del derecho a la propia imagen, además de resultar una novedad en nuestra historia constitucional, constituye una rareza en el Derecho Constitucional comparado ${ }^{1}$.

Tampoco los textos internacionales recogen este derecho fundamental. No lo hace el Convenio Europeo de Derechos Humanos, de 1950, lo que parece lógico dada la fecha de su aprobación; pero tampoco la mucho más reciente Carta de Derechos Fundamentales de la Unión Europea, de 7 de diciembre de $2000^{2}$, sin que ello signifique que dichos textos no confieran protección al uso inconsentido de la imagen ajena.

Esta falta de reconocimiento autónomo en nuestro entorno más cercano, debida en parte a su reciente consideración como derecho subjetivo ${ }^{3}$, así como la falta de antecedentes propios, hace especialmente relevante el papel del Tribunal Constitucional en su definición constitucional.

Ha sido en sede de recurso de amparo donde se han suscitado los conflictos que han permitido al Tribunal Constitucional elaborar su concepción sobre este derecho fundamental.

Como no podía ser de otro modo, la mayor parte de estas resoluciones se han dictado con ocasión de las tensiones suscitadas por la actividad de los medios de comunicación. El constituyente, en el artículo 20.4 CE ya adelantaba la problemática relación entre las libertades comunicativas y los derechos reconocidos en el artículo 18.1 CE, al destacar que «estas libertades tienen su límite en el respeto a los derechos reconocidos en este Título, en los preceptos de las leyes que los desarrollen y, especialmente, en el derecho al honor, a la intimidad, a la propia imagen y a la protección de la juventud y de la infancia».

${ }^{1}$ Únicamente Portugal lleva la protección de la propia imagen a su norma fundamental y lo hace en la reforma de 1982, por lo que, en contra de la opinión más extendida, no sería el texto portugués el que influiría en el constituyente español, sino a la inversa.

${ }^{2}$ Uno y otro, en una redacción muy similar, reconocen el derecho al respeto a la vida privada y familiar. En el caso del CEDH, además, al domicilio y a la correspondencia, y en el de la Carta, a las comunicaciones.

${ }^{3}$ Una magnífica exposición sobre el origen de este derecho subjetivo puede encontrarse en A. AZURMENDI ADÁRRAGA, El derecho a la propia imagen: su identidad y aproximación al derecho a la información, Madrid, Civitas, 1997, p. 47 y ss. 
Conviene precisar que el tratamiento otorgado por el Tribunal Constitucional a esta tensión será diferente en función de que nos situemos en el ámbito del ejercicio de la libertad de información o nos movamos en el campo de la prensa de entretenimiento, la denominada prensa rosa o del corazón.

También en el ámbito de las relaciones laborales se han producido conflictos, aunque en número menor, que han requerido la intervención del Tribunal Constitucional. Uno, como el caso del cortador de jamón que no quería participar en una exhibición pública donde su imagen sería captada por los medios de comunicación, ha dado al Tribunal la oportunidad de pronunciarse por primera vez de una manera completa acerca de la configuración de este derecho fundamental. Otro, relativo a la libertad de configuración de la propia apariencia, ha contribuido a esta definición desde un punto de vista negativo.

\section{La configuración constitucional del derecho a la propia imagen en la jurisprudencia del Tribunal Constitucional}

El derecho a la propia imagen, derecho que entre nosotros aparece por primera vez consagrado en la Constitución Española de 1978, ha sido objeto de atención por parte del Tribunal Constitucional con ocasión de una serie de recursos de amparo que, aunque no muy numerosos, han permitido elaborar toda una doctrina sobre su relación con los otros derechos de la personalidad consagrados en el artículo 18.1 CE, sobre su contenido y sus límites.

Su inclusión en la ambigua categoría de los derechos de la personalidad, admitida por el Tribunal Constitucional, podría estar en el origen de muchas de las dudas iniciales que surgieron en relación con el carácter autónomo de este derecho y su relación con otros derechos de la personalidad ${ }^{4}$.

${ }^{4}$ La construcción de los derechos de la personalidad tiene lugar en el seno del Derecho Civil a finales del s. XIX y comienzos del Xx. Sobre esta categoría se produjo una pluralidad de concepciones que se diferenciaban según se admitiera la existencia de un único derecho de la personalidad del que son manifestaciones concretas todas las variedades posibles, o sostuvieran la existencia de tantos derechos autónomos -pese a su común fundamentocomo fueran los ejemplos de articulación de la protección jurídica para cualquier manifestación de la personalidad; o, finalmente, defendieran que es mejor hablar de bienes de la personalidad para subrayar que se trata de algo inmaterial, fuera de comercio. Al respecto puede consultarse P. LuCAS MuRILlo DE LA CuEVA, «El derecho a la intimidad», en AA. VV., Honor, intimidad y propia imagen, Cuadernos de Derecho Judicial, núm. XXXV, Madrid, Consejo General del Poder Judicial, 1993, p. 25. Entre nosotros se ha ocupado de la cuestión J. CASTÁn ToBeÑas, «Los derechos de la personalidad», separata de la Revista General de Legislación y Jurisprudencia, Madrid, 1952. Asimismo, encontramos una exposición muy detallada sobre esta construcción en sus múltiples acepciones en M. GITRAMA GoNZÁLEZ, Voz «Imagen (derecho a la propia)», Nueva enciclopedia jurídica Seix, vol. XI, Barcelona, Seix, 1962. 
De esta manera, una de las primeras cuestiones que el Tribunal tuvo que afrontar en relación con el derecho fundamental a la propia imagen fue la relativa a su carácter autónomo con respecto a los derechos al honor y, sobre todo, a la intimidad.

Sobre este particular, el Tribunal ha destacado en numerosas ocasiones que «se trata de un derecho autónomo que dispone de un ámbito específico de protección $(\ldots) \gg^{5}$.

Sin embargo, también se ha puesto de relieve su íntima conexión con el derecho al honor y, sobre todo, con el derecho a la intimidad:

«En la Constitución Española este derecho se configura como un derecho autónomo, aunque ciertamente, en su condición de derecho de la personalidad, derivado de la dignidad y dirigido a proteger el patrimonio moral de las personas, guarda una muy estrecha relación con el derecho al honor y, sobre todo, con el derecho a la intimidad, proclamados ambos en el mismo art. 18.1 del Texto constitucional» ${ }^{6}$.

\section{Asimismo:}

«Los derechos a la intimidad personal y a la propia imagen, garantizados por el art. 18.1 de la Constitución, forman parte de los bienes de la personalidad que pertenecen al ámbito de la vida privada. Salvaguardan estos derechos un espacio de intimidad personal y familiar que queda sustraído a intromisiones extrañas. Y en ese ámbito de la intimidad, reviste singular importancia la necesaria protección del derecho a la propia imagen frente al creciente desarrollo de los medios y procedimientos de captación, divulgación y difusión de la misma» ${ }^{7}$.

Esta estrecha relación tiene su reflejo en la definición de su objeto, que estaría conformado, según la jurisprudencia constitucional, por «el interés del sujeto en evitar la difusión incondicionada de su aspecto físico, que constituye el primer elemento configurador de su intimidad y de su esfera personal, y en cuanto instrumento básico de identificación y proyección exterior y factor imprescindible para su propio reconocimiento como individuo» ${ }^{8}$.

Queda así evidenciada en la jurisprudencia la íntima conexión entre este derecho y el derecho a la intimidad: «Esta estricta vinculación con la salvaguarda de la intimidad, y la dimensión teleológica del derecho a la propia

${ }^{5}$ SSTC 231/1988, de 2 de diciembre, F.J. 3.. ; 99/1994, de 11 de abril, F.J. 5. ; 81/2001, de 26 de marzo, F.J. $2 .^{\circ}$ y 139/2001, de 18 de junio, F.J. $4 .^{\circ}$, entre otras.

${ }^{6}$ STC 81/2001, de 26 de marzo, F.J. 2. ${ }^{\circ}$.

${ }^{7}$ STC 170/1987, de 21 de noviembre, F.J. 4. ${ }^{\circ}$.

${ }^{8}$ STC 99/1994, de 11 de abril, F.J. 5. ${ }^{\circ}$. 
imagen, hacen que la dimensión constitucional del tema quede restringida a este concreto ámbito de natural reserva de la propia esfera íntima»?

Si bien es cierto que con el paso del tiempo en la jurisprudencia constitucional parece apreciarse un esfuerzo por individualizar ambos derechos, creo que el Tribunal siempre tuvo claro el carácter autónomo del derecho a la propia imagen. A mi juicio, de las primeras sentencias se desprende que ambos derechos protegen un ámbito de reserva propio frente a injerencias externas. El derecho a la intimidad, vedando cualquier tipo de irrupción en la esfera más reservada que el individuo quiere mantener al margen del conocimiento ajeno, y el derecho a la propia imagen, impidiendo que los demás capten, reproduzcan o publiquen la imagen sin el consentimiento del titular.

No comparte esta interpretación la doctrina, que de manera mayoritaria considera que durante un tiempo el Tribunal Constitucional no tuvo claro el carácter autónomo del derecho a la propia imagen, que solamente después aparecería desligado del derecho a la intimidad ${ }^{10}$. A pesar de lo confuso que pueda resultar el hecho de que se defina el ámbito de protección de la propia imagen aludiendo a la esfera de la propia reserva íntima, creo que en la jurisprudencia constitucional se distinguen ambos derechos. Sucede, sin embargo, que el Tribunal Constitucional argumenta desde la concepción del derecho a la propia imagen como integrante de ese ámbito personal y reservado, pero no necesariamente íntimo, que pertenece a todo individuo y que no puede ser sobrepasado sin la voluntad de su titular.

La estrecha conexión entre ambos derechos se refleja además en que se encuentran «estrictamente vinculados a la propia personalidad, derivados sin duda de la dignidad de la persona, que reconoce el art. 10 de la CE, y que implican la existencia de un ámbito propio y reservado frente a la acción y conocimiento de los demás, necesario -según las pautas de nuestra culturapara mantener una calidad mínima de la vida humana. Se muestran así esos derechos como personalísimos y ligados a la misma existencia del individuo» ${ }^{11}$.

En lo que respecta a su contenido, el Tribunal ha considerado que «la facultad otorgada por este derecho, en tanto que derecho fundamental, consiste en esencia en impedir la obtención, reproducción o publicación de la propia imagen por parte de un tercero no autorizado, sea cual sea la finali-

\footnotetext{
${ }^{9}$ Ibídem.

${ }^{10}$ Esta es la postura, entre otros, de A. Pascual Medrano, El derecho fundamental a la propia imagen, Cizur Menor, Aranzadi, 2003, p. 48 y ss. En la misma línea, Ruiz Miguel, interpretando las SSTC 99/1994 y 117/1994, ha destacado que «el derecho a la propia imagen se concibe como vinculado al derecho a la intimidad porque se estima que sirve para salvaguardar este, es decir, una esfera de propia reserva personal frente a intromisiones ilegítimas provenientes de terceros». C. RUIZ Miguel, La configuración constitucional del derecho a la intimidad, Madrid, Tecnos, 1995, p. 111.

${ }^{11}$ STC 231/1988, de 2 de diciembre, FJ 3.‥
} 
dad -informativa, comercial, científica, cultural, etc.- perseguida por quien la capta o la difunde» ${ }^{12}$.

La alusión a la obtención o captación, reiterada cada vez que se ha pronunciado sobre este derecho fundamental, amplía su radio de acción hasta el extremo de incluir en su ámbito de protección la mera captación ${ }^{13}$ de la imagen sin el consentimiento del titular. Este hecho ha sido duramente criticado por la doctrina, que no ve razones para penalizar la mera captación, hecho que no encuentra parangón en el Derecho comparado ${ }^{14}$.

Atendiendo a las palabras del Tribunal Constitucional, pocas dudas pueden caber de que la mera captación de la imagen forma parte del ámbito de protección del derecho. Ahora bien, una cosa es afirmar esto y otra muy distinta hacer operativa esta facultad en relación con la mera captación sin poner en riesgo otros derechos, como el derecho a la información que, como veremos, ampara la difusión de la imagen si concurren determinados requisitos.

En lo que respecta a la imagen cuya captación, publicación o difusión pueda provocar lesión en el derecho fundamental, resulta esencial que en ella sea reconocible su titular. En otro caso, no nos situaríamos en el ámbito del derecho fundamental, pues difícilmente podría reconducirse la lesión del derecho a la dignidad de la persona. En este sentido, el Tribunal ha destacado como «el aspecto físico, en cuanto instrumento básico de identificación y proyección exterior y factor imprescindible para el propio reconocimiento como individuo, constituye el primer elemento configurador de la esfera personal de todo individuo» ${ }^{15}$.

$\mathrm{O}$, más gráficamente incluso,

«en su dimensión constitucional, el derecho a la propia imagen (art. 18.1 CE) se configura como un derecho de la personalidad, que atribuye a su titular la facultad de disponer de la representación de su aspecto físico que permita su identificación, lo que conlleva tanto el derecho a

${ }^{12}$ SSTC 81/2001, 26 de marzo, F.J. 2. ${ }^{\circ}$, 139/2001, de 18 de junio, F.J. 4. ${ }^{\circ}$, entre otras.

${ }^{13}$ En este sentido se pronuncian, entre otros, BlASCO GASCÓ, que lo considera una clara limitación a la libertad individual no suficientemente justificada. F. P. BLAsco Gascó, «Algunas cuestiones del derecho a la propia imagen», Bienes de la personalidad, Murcia, Universidad de Murcia, 2008, p. 15. En idéntico sentido, M. GITRAMA GoNZÁLEZ, «El derecho a la propia imagen, hoy», en Homenaje a J. B. de Goytisolo, vol. VI, Madrid, Consejo General del Notariado, 1990, p. 215 o J. R. DE VERDA y BEAMONTE, «El derecho a la propia imagen», en J. R. DE VERDA Y BEAMONTE (coord.), Veinticinco años de aplicación de la Ley Orgánica 1/1982, de 5 de mayo, de Protección civil del derecho al honor, a la intimidad personal y familiar y a la propia imagen, Cizur Menor, Thomson-Aranzadi, 2007, pp. 162 y 163 .

${ }^{14}$ En lo que respecta a la situación en el ordenamiento italiano, puede consultarse A. DE CuPIS, I diritti della personalità, Giuffrè, Milán, 1950. Más reciente, F. Galgano, Diritto Civile e commerciale, Padua, Cedam, 1990, p. 165.

${ }^{15}$ STC 156/2001, de 2 de julio, F.J. 6. ${ }^{\circ}$. 
determinar la información gráfica generada por los rasgos físicos que le hagan reconocible que puede ser captada o tener difusión pública, como el derecho a impedir la obtención, reproducción o publicación de su propia imagen por un tercero no autorizado (STC 81/2001, de 26 de marzo, FJ 2)» ${ }^{16}$.

De esta manera, la recognoscibilidad constituye un elemento fundamental para que podamos hablar de una lesión al derecho a la propia imagen. El uso inconsentido de la imagen que no permita la identificación del titular constituye, a mi juicio, un supuesto de intromisión ilegítima encuadrable en el marco de la L. O. 1/82, de 5 de mayo, de Protección Civil del derecho al honor, a la intimidad personal y a la propia imagen, pero no alcanza al derecho fundamental.

En lo que respecta a su contenido, además de proteger la captación y difusión de la imagen propia, el Tribunal ha dado a entender en alguna ocasión que esta protección podría extenderse a otros atributos de la personalidad, como la voz o el nombre:

«El derecho a la propia imagen, reconocido por el art. 18.1 de la Constitución al par de los del honor y la intimidad personal, forma parte de los derechos de la personalidad y como tal garantiza el ámbito de libertad de una persona respecto de sus atributos más característicos, propios e inmediatos como son la imagen física, la voz o el nombre, cualidades definitorias del ser propio y atribuidas como posesión inherente e irreductible a toda persona. En la medida en que la libertad de esta se manifiesta en el mundo físico por medio de la actuación de su cuerpo y las cualidades del mismo, es evidente que con la protección de la imagen se salvaguarda el ámbito de la intimidad y, al tiempo, el poder de decisión sobre los fines a los que hayan de aplicarse las manifestaciones de la persona a través de su imagen, su identidad o su voz» ${ }^{17}$.

Esta alusión, reiterada recientemente ${ }^{18}$, no ha llegado a tener una aplicación concreta. De hecho, el Tribunal Constitucional en alguna ocasión ha negado que la grabación de la voz sin más resulte ilícita:

«Como conclusión, pues, debe afirmarse que no constituye contravención alguna del secreto de las comunicaciones la conducta del interlocutor en la conversación que graba esta (que graba también, por lo tanto, sus propias manifestaciones personales, como advierte el Ministerio Fiscal en su escrito de alegaciones). La grabación en sí -al margen su empleo ulterior- solo podría constituir un ilícito sobre la base del reconocimiento de un hipotético "derecho a la voz" que no cabe identificar en nuestro orde-

\footnotetext{
${ }^{16}$ STC 72/2007, de 16 de abril, F.J. 3. ${ }^{\circ}$.

${ }^{17}$ STC 117/1994, de 25 de abril, F.J. 3. ${ }^{\circ}$.

${ }^{18}$ STC 23/2010, de 27 de abril, F.J. 4. ${ }^{\circ}$.
} 
namiento, por más que sí pueda existir en algún Derecho extranjero. Tal protección de la propia voz existe solo, en el Derecho español, como concreción del derecho a la intimidad y, por ello mismo, solo en la medida en que la voz ajena sea utilizada ad extra y no meramente registrada, y aun en este caso cuando dicha utilización lo sea con determinada finalidad (art. 7.6 de la citada Ley Orgánica 1/1982: "utilización de la voz de una persona para fines publicitarios, comerciales o de naturaleza análoga")» ${ }^{19}$.

Sin embargo, creo que este pronunciamiento no es suficiente para negar que la voz cuenta con protección en nuestro ordenamiento. Hay que tener presente que, además de afrontarse la cuestión desde la perspectiva del secreto de las comunicaciones, se habla de la grabación y no se dice nada de su posterior uso ${ }^{20}$.

No puede obviarse además que la L. O. 1/82, de 5 de mayo, considera en su art. 7.6 como intromisión ilegítima «la utilización del nombre, de la voz o de la imagen de una persona para fines publicitarios, comerciales o de naturaleza análoga». La propia jurisprudencia ha aplicado este precepto para sancionar el uso inconsentido del nombre con fines publicitarios ${ }^{21}$.

La única duda, por tanto, estriba en discernir si el uso inconsentido del nombre o de la voz estarían protegidos, entre nosotros, por el derecho fundamental reconocido en el art. 18.1 CE, lo que atribuiría protección con independencia del fin que persiguiera el uso no autorizado de estos atributos.

La postura mayoritaria pasa por rechazar este concepto extensivo de imagen que contiene la L. O. 1/82, de 5 de mayo y que incluye la voz y el nombre, entendiendo que este no alcanza al derecho fundamental, sino que se concreta en la existencia de una acción civil por su uso inconsentido con un fin lucrativo. $\mathrm{O}$, por decirlo con otras palabras, que la protección del nombre o de la voz únicamente puede predicarse del derecho de naturaleza patrimonial y no del de rango constitucional ${ }^{22}$.

${ }^{19}$ STC 114/1984, de 29 de noviembre, F.J. 8..

${ }^{20}$ En este sentido, Ruiz Miguel ha considerado que el derecho a la propia voz solamente existiría como concreción del derecho a la intimidad. Esta conclusión la extrae de este pronunciamiento, ya que según el autor, para el Tribunal Constitucional la grabación de la voz únicamente podría constituir un ilícito atendiendo a su empleo ulterior. C. Ruiz MigueL, La configuración constitucional del derecho a la intimidad, ob. cit., p. 112.

${ }^{21}$ SSTS de 21 de enero de 1988 (caso Antonio Gades), de 5 de octubre de 1989 (caso César Manrique) y de 26 de noviembre de 1990 (caso Marqués de Bradomín).

${ }^{22}$ En este sentido se pronuncia PASCUAL MEDRANO: «mientras que el titular está facultado para decidir sobre la captación, reproducción o publicación de su propia imagen, cualquiera que sea la finalidad de dichos usos, respecto al nombre y a la voz, únicamente dispone de la facultad de decidir sobre su utilización comercial. La voz y el nombre se protegen así solo en cuanto se utilicen con fines comerciales, publicitarios o similares». A. PASCUAL MEDRANO, El derecho fundamental a la propia imagen. Fundamento, contenido y límites, ob. cit., p. 62. En el mismo sentido, J. R. DE VERDA Y BEAMONTE, que señala que «lo que sucede es que la tutela civil, no solo se extiende a la imagen, sino igualmente a otros atributos de la persona, 
Para terminar, conviene destacar como el Tribunal Constitucional ha reconocido el carácter dual del derecho a la propia imagen que, además de un derecho fundamental contenido en la Constitución, constituye un derecho patrimonial derivado de la naturaleza de la imagen como bien sujeto a tráfico mercantil.

En este sentido, ha destacado que «mediante la autorización del titular, la imagen puede convertirse en un valor autónomo de contenido patrimonial sometido al tráfico negocial y ello inducir a confusión acerca de si los efectos de la revocación se limitan al ámbito de la contratación o derivan del derecho de la personalidad» ${ }^{23}$.

«El derecho constitucional a la propia imagen no se confunde con el derecho de toda persona a la explotación comercial inconsentida -e incluso en determinadas circunstancias la consentida- de la imagen de una persona que puede afectar a su derecho fundamental a la propia imagen» ${ }^{24}$.

Se reconoce así un fenómeno que cobra cada vez más actualidad, el valor patrimonial de la imagen, que se ha convertido en objeto del tráfico negocial. Esta constatación ha obligado al Tribunal a pronunciarse acerca de los elementos que conformarían una y otra esfera del derecho a la propia imagen. De esta manera, en su jurisprudencia ha ido señalando cuestiones que, por su naturaleza, forman parte del derecho patrimonial, sin alcanzar al derecho fundamental. Entre ellas, las relativas al uso comercial de la imagen de una persona fallecida (STC 231/1988, de 2 de diciembre), algunas cuestiones atinentes a la revocación del consentimiento (STC 117/1994, de 25 de abril) o el uso inconsentido de la imagen de un personaje de ficción encarnado por un actor con fines publicitarios (STC 81/2001, de 26 de enero). Veámoslo con más detenimiento.

En la STC 231/1988, de 2 de diciembre, el Tribunal resuelve el recurso de amparo interpuesto por la viuda de un conocido torero con motivo de la comercialización de un vídeo sobre la vida de este, en el que se contenían momentos de su vida y de su muerte, producida como consecuencia de una cogida. El Tribunal, en lo que respecta a la petición de amparo por vulneración de la propia imagen, destaca lo siguiente:

«En este aspecto, el "derecho a la imagen" que se invoca (y al que la demandante concede especial relevancia) es, en realidad, el derecho a dis-

que también son bienes de la personalidad, en la medida en que, como sucede con la figura, identifican al individuo y lo hacen reconocible ante la sociedad, por lo que han de ser considerados objetos de un derecho, distinto al de la propia imagen». J. R. DE VERDA Y BEAMONTE, «El derecho a la propia imagen», en J. R. DE VERDA Y BEAMONTE (coord.), Veinticinco años de aplicación de la Ley Orgánica 1/1982, de 5 de mayo, de Protección civil del derecho al honor, a la intimidad personal y familiar y a la propia imagen, ob. cit., pp. 162 y 163.

${ }^{23}$ STC $117 / 1994$, de 25 de abril, F.J. 3. ${ }^{\circ}$.

${ }^{24}$ STC 81/2001, de 26 de marzo, F.J. 2. ${ }^{\circ}$. 
poner de la imagen de una persona desaparecida y de su eventual explotación económica, protegible, según la Ley 1/1982 en vías civiles, y susceptible de poseer un contenido patrimonial, pero derecho que no puede ser objeto de tutela en vía de amparo, ya que, una vez fallecido el titular de ese bien de la personalidad, no existe ya un ámbito vital que proteger en cuanto verdadero objeto del derecho fundamental aun cuando pudieran pervivir sus efectos patrimoniales» ${ }^{25}$.

Por tanto, aun cuando existe un interés en tutelar la imagen de personas fallecidas, este asunto no puede reconducirse al ámbito de los derechos fundamentales del desaparecido, que se extinguen con la muerte de su titular.

En la STC 117/1994, de 25 de abril, el Tribunal Constitucional resuelve un recurso de amparo relativo a la revocabilidad del consentimiento. Transcribimos algunas de sus palabras:

«Cierto que, mediante la autorización del titular, la imagen puede convertirse en un valor autónomo de contenido patrimonial sometido al tráfico negocial y ello inducir a confusión acerca de si los efectos de la revocación se limitan al ámbito de la contratación o derivan del derecho de la personalidad. Esto es lo que puede determinar situaciones como la que aquí se contempla porque los artistas profesionales del espectáculo (o quienes pretenden llegar a serlo), que ostentan el derecho a su imagen como cualquier otra persona salvo las limitaciones derivadas de la publicidad de sus actuaciones o su propia notoriedad, consienten con frecuencia la captación o reproducción de su imagen, incluso con afección a su intimidad, para que pueda ser objeto de explotación comercial; mas debe afirmarse que también en tales casos el consentimiento podrá ser revocado, porque el derecho de la personalidad prevalece sobre otros que la cesión contractual haya creado. Más, en esos supuestos de cesión voluntaria de la imagen o de ciertas imágenes, el régimen de los efectos de la revocación (prevista en el art. 2.3 de la L. O. 1/1982 como absoluta) deberá atender a las relaciones jurídicas y derechos creados, incluso a favor de terceros, condicionando o modulando algunas de las consecuencias de su ejercicio; y corresponde a los Tribunales ordinarios la ponderación de los derechos en conflicto en tales casos, sin perjuicio de la que a este Tribunal compete, únicamente desde la perspectiva constitucional» ${ }^{26}$.

Por tanto, en la cuestión de la revocación de un consentimiento previamente otorgado para el uso de la propia imagen, el Tribunal considera que la vertiente fundamental del derecho prevalece, debiendo otorgarse valor a la revocación siempre y cuando se tutelen todos los intereses creados al amparo de la anterior cesión. Por un lado, se afecta al derecho fundamental pero, por

${ }^{25}$ STC 231/1988, de 2 de diciembre, F.J. 3..

${ }^{26}$ STC $117 / 1994$, de 25 de abril, F.J. 3. ${ }^{\circ}$. 
otro, se remite a los tribunales ordinarios para que sopesen los distintos intereses en juego, al considerar que los detalles concretos forman parte del derecho patrimonial. Creo que en este caso, como en ningún otro, se aprecia la confusión entre ambos planos.

En la STC 81/2001, de 26 de marzo, el Tribunal Constitucional se pronuncia acerca de los derechos derivados del uso inconsentido de la imagen de un personaje de ficción, encarnado por un actor:

«(...) la imagen reproducida, en este caso concreto, tampoco afectaba a lo que hemos denominado dimensión personal y no patrimonial del derecho a la imagen, ya que se trataba de un simple dibujo en blanco y negro realizado por ordenador de unas piernas cruzadas y enfundadas en unos pantalones negros y calzadas con zapatillas deportivas blancas que, además, representaban al personaje en su faceta de actor. Esta doble circunstancia permite afirmar que, con independencia de la cuestión debatida en casación acerca de si esta imagen era suficiente o no para identificar al recurrente y podía por ello generar una vulneración del valor comercial de esa imagen, la referida representación gráfica no se refiere ni afecta al recurrente como sujeto en su dimensión personal, individual o privada, sino a lo sumo en cuanto personaje popularizado a través de sus apariciones televisivas, con lo que, como queda dicho, en ese anuncio no quedaba concernido el bien jurídico protegido por el derecho fundamental a la propia imagen ${ }^{27}$.

Conviene ser cautelosos a la hora de discernir la existencia autónoma de un derecho patrimonial a la propia imagen, escindido del derecho de rango fundamental. En este último caso, por ejemplo, tanta relevancia tiene en la argumentación del Tribunal el hecho de que la imagen represente a un personaje de ficción, como que no se trate de una fotografía o un dibujo que incluya el rostro. En este supuesto, al Tribunal le hubiera resultado mucho más difícil escindir el personaje de la persona que lo ha creado y que lo interpreta en exclusiva. Además, la imagen, en tanto que atributo de la personalidad, sería la misma con independencia de que representara al actor en esta faceta o al margen de ella.

Más allá de estas precisiones, no contamos con una construcción general sobre los contenidos que cabe incluir en el derecho moral y patrimonial a la propia imagen, respectivamente ${ }^{28}$.

${ }^{27}$ STC 81/2001, de 26 de marzo, F.J. 3. ${ }^{\circ}$.

28 «Pues bien, en el caso aquí enjuiciado no cabe duda de que el derecho concernido no es el derecho constitucional a la propia imagen. Para llegar a esta conclusión y resolver el caso planteado, no es necesario elaborar en abstracto una doctrina general acerca de los elementos que permiten distinguir entre la dimensión moral y patrimonial del derecho a la propia imagen» (STC 81/2001, de 26 de marzo, F.J. 3. ${ }^{\circ}$ ). 
Parecería lógico sostener, de entrada, que los desencuentros relativos a los términos de un acuerdo concreto sobre cesión de la imagen, como el relativo a la cuantía de la contraprestación, si la hay, forman parte del derecho patrimonial. Sin embargo, no cabe precipitarse, dado que la utilización de la imagen sin consentimiento afecta al derecho fundamental y, en ocasiones, aun existiendo acuerdo previo, la publicación de imágenes más allá de los términos del contrato puede afectar a la esfera moral y, por consiguiente, constitucional del derecho.

Lo único que cabe es realizar un análisis caso por caso, lo que a la postre, contribuye a degradar en cierta medida el derecho fundamental ante la imposibilidad de realizar a priori una determinación clara del contenido propio del derecho fundamental frente al patrimonial.

\section{EI derecho a la propia imagen en el ámbito de las relaciones labora- les}

En el ámbito de las relaciones laborales se han suscitado conflictos relativos al derecho a la propia imagen desde dos ópticas diversas, la facultad del trabajador de configurar su propia apariencia y la posibilidad del empresario de limitar el derecho a la propia imagen de un trabajador, obligándolo a participar en un acto donde su imagen sería captada y difundida por los medios de comunicación.

\section{III.1. El derecho a configurar la imagen propia}

Según la jurisprudencia del Tribunal Constitucional, el derecho a la propia imagen consiste en la facultad de impedir la captación, reproducción o publicación de la imagen propia y, en consecuencia, la facultad de decidir el uso de la representación gráfica de nuestra imagen. Sin embargo, cabe preguntarse por el momento previo a esa facultad de representación: la configuración de nuestra apariencia con libertad, sin injerencias externas.

Ha sido en el ámbito de las relaciones laborales donde de manera natural se han planteado conflictos relativos a los límites de esta libertad de configuración de nuestra apariencia ${ }^{29}$. Asimismo, en los últimos tiempos la cuestión ha adquirido actualidad con la polémica en torno al uso del velo islámico y del burka en lugares públicos, prácticas que se enmarcan en el ejercicio de

${ }^{29}$ A este respecto puede consultarse J. GARCía ORTEGA, «La protección del derecho a la imagen en el ámbito de las relaciones laborales», en J. R. DE VERDA Y BEAMONTE (coord.), Veinticinco años de aplicación de la Ley Orgánica 1/1982, de 5 de mayo, de Protección civil del derecho al honor, a la intimidad personal y familiar y a la propia imagen, ob. cit. Asimismo, L. CORDERo SAAVEDRA, «Derecho a la propia imagen y contrato de trabajo», Revista Española de Derecho del Trabajo, 101, 2000. 
la libertad religiosa, pero que también pueden ser consideradas desde esta perspectiva $^{30}$.

La configuración de la propia apariencia ha sido objeto de atención por parte del Tribunal Constitucional en dos ocasiones ${ }^{31}$ : el conocido asunto del barman despedido como consecuencia de su negativa reiterada a afeitarse la barba (STC 170/87, de 30 de octubre) ${ }^{32}$ y el caso de un policía que resultó sancionado por llevar el pelo largo y recogido en una coleta (STC 120/96, de 8 de julio).

En ambos casos el Tribunal Constitucional evita manifestarse sobre la existencia de este pretendido derecho y sobre su fundamento expreso. Esta opción del TC resulta llamativa, porque pocas dudas caben de que a todos nos asiste el derecho a conformar nuestra propia apariencia física y que ello constituye una manifestación de nuestra identidad personal y del libre desarrollo de nuestra personalidad, amparados por la Constitución. Ahora bien, esto no quiere decir, lógicamente, que se trate de derechos absolutos. Este derecho, como todos, tiene sus límites en otras normas como las relativas a higiene y salud, y seguridad en el trabajo en el ámbito de las relaciones laborales, o la exigencia de uniformes en el mismo ámbito.

El Tribunal Constitucional no ha podido negar la evidencia de la existencia de este derecho, aunque hasta la fecha ha evitado incardinarlo en el ámbito del artículo 18.1 CE.

En el primer caso, el resuelto por la STC 170/87, de 30 de octubre, lo hace trasladando el peso de la argumentación al ámbito de las relaciones laborales para tratar de analizar si existía una justificación que amparara la decisión del empresario de exigir al trabajador que se afeitara la barba. En este caso, la respuesta que se da y que a nuestro juicio es la correcta, denegando el amparo al trabajador, discurre sin embargo por unos senderos que parecen tomados para evitar una declaración explícita sobre el asunto que aquí nos ocupa. En palabras del Tribunal, «no es, por tanto, una difusión o captación ilícita de su propia imagen contraria al art. 18.1 CE, ni tampoco la decisión personal sobre su apariencia física lo que se discute en este proceso, sino si esta decisión puede o no limitarse o condicionarse en virtud de las relaciones laborales en que desarrolla su actividad profesional» ${ }^{33}$.

${ }^{30}$ Un análisis de esta cuestión desde la óptica del derecho a la propia imagen se contiene en A. CuERDA RIEZU, «El velo islámico y el derecho a la propia imagen», Parlamento y Constitución, Anuario, 11, 2008.

${ }^{31}$ En una tercera, el recurso de amparo quedó extinguido por satisfacción extraprocesal. El conflicto que subyacía venía provocado por la imposición a las trabajadoras del AVE del uso de falda en el uniforme (STC 84/2006, de 27 de marzo).

${ }^{32}$ Un comentario a esta resolución puede encontrarse en F. PÉREZ DE LOS COBOS ORIHUEL, «Sobre el derecho a la propia imagen (a propósito de la STC 170/87, de 30 de octubre)», Poder Judicial, 10, 1988.

${ }^{33}$ STC 170/87, de 30 de octubre, F.J. 4. ${ }^{\circ}$. 
Como ha destacado Gorrotxategi Azurmendi, «lo único que queda claro, a través de la sentencia, es que los deberes y relaciones jurídicas que el ordenamiento jurídico regula -entre los que se encuentran el contrato de trabajo y el poder directivo, dentro de los márgenes permitidos por la ley, del empresario- pueden limitar los derechos fundamentales del art. 18.1. Si entre ellos se encuentra la decisión sobre el propio aspecto físico es cuestión no resuelta. La afirmación final en el sentido de que estos derechos no resultan afectados ni guardan relación con la cuestión resuelta, sirve solo para quitar razón al demandado, pero, en sí, no explica nada ${ }^{34}$. Además, como ha señalado Alegre Martínez, «si el derecho cede es porque existe» ${ }^{35}$.

En el caso resuelto por la STC 116/1996, de 8 de julio, la estimación del amparo se fundamenta en que la sanción se había impuesto vulnerando el principio de legalidad, lo que evita al Tribunal el tener que pronunciarse sobre este asunto, aun cuando eso no le impide pronunciarse sobre otras vulneraciones también alegadas.

En general, la doctrina considera que el derecho a conformar la propia apariencia no forma parte del derecho fundamental a la propia imagen ${ }^{36}$. No comparte, sin embargo, esta postura mayoritaria Blasco Gascó, para el que «el derecho a la propia imagen también es, y posiblemente con carácter previo y fundamental, el derecho a conformar tales rasgos físicos. Se trata de un derecho a la imagen no en sentido gráfico (que capten o no la imagen), sino en sentido somático o estético: el derecho a definir, a determinar, a configurar y a modificar libremente la propia apariencia exterior. El derecho a la propia imagen es, ante todo, el derecho a determinarla, a individualizarla frente a los demás. Y este derecho es previo al poder de controlar (y a participar de las ganancias) el uso que se haga de la imagen, es decir, al derecho

${ }^{34}$ M. GorRotXATEgi AZURmend, «El derecho a la imagen, objeto de la jurisprudencia constitucional», Revista Vasca de Administración Pública, 42, 1995, pp. 366 y 367. En el mismo sentido se pronuncia CUERDA RIEZU, para el que «por lo que se refiere a la doctrina del Tribunal Constitucional, este no ha llegado a rechazar que el derecho a la imagen comprenda la libre configuración del aspecto físico». A. CUERDA RIEZU, «El velo islámico y el derecho a la propia imagen», ob. cit., p. 253.

${ }^{35}$ M. A. Alegre Martínez, El derecho a la propia imagen, Madrid, Tecnos, 1997, p. 91.

${ }^{36}$ PARDO FALCón ha considerado que «el derecho a la propia imagen no incluye lo que, desde un punto de vista estrictamente gramatical o semántico, pudiera parecer: el derecho de cada uno a llevar el aspecto que estime oportuno; jurídicamente hablando, este último derecho debe ser entendido, como hace nuestra jurisdicción constitucional, como otra manifestación del más genérico derecho a la intimidad». J. PARDO FALCón, «Los derechos del artículo 18 de la Constitución Española en la jurisprudencia del Tribunal Constitucional», Revista Española de Derecho Constitucional, 34, 1992, p. 167. También Pascual MedRANO considera que «el derecho a la propia apariencia nada tiene que ver con el derecho a la propia imagen. Estamos más bien ante una manifestación o proyección de la libertad individual general (art. 1.1 CE), que puede encontrar tutela por parte del TC si dicha apariencia es fuente de discriminaciones injustificadas (art. 14 CE)». A. PASCUAL MEdRano, ob. cit., p. 65 , nota 6. 
a fiscalizar la representación, captación, reproducción o publicación de nuestra imagen o, en negativo, a que no se haga sin nuestro consentimiento, salvo que se trate de algún supuesto exceptuado en el artículo 8 de L. O. $1 / 1982 »^{37}$.

Ciertamente, nadie puede poner en duda la existencia de un derecho a conformar nuestra apariencia física, aunque podamos discutir su fundamento preciso. El derecho a la propia imagen reconocido en el artículo $18.1 \mathrm{CE}$ parece ser además el fundamento natural. Si hablamos de la reserva de un ámbito libre de injerencias, como el Tribunal Constitucional ha hecho en múltiples ocasiones, en ese ámbito debería situarse además la libertad del individuo de conformar con libertad su apariencia física, por más que el Tribunal Constitucional no haya querido pronunciarse al respecto y que la L. O. 1/82, contemple el derecho a la propia imagen desde otra perspectiva. De todos modos, queda claro que el Tribunal no considera que el derecho a configurar la propia apariencia forme parte del derecho fundamental a la propia imagen.

\section{III.2. El derecho a la propia imagen como límite en las relaciones contrac- tuales}

Uno de los casos emblemáticos relativos al derecho a la propia imagen tiene como escenario precisamente el campo de las relaciones laborales: la STC 99/1994, de 11 de abril ${ }^{38}$. Este caso, además de presentarnos la posición del TC acerca de la siempre polémica materia de la restricción de los derechos fundamentales en el ámbito laboral, supone el primer planteamiento general sobre este derecho fundamental ${ }^{39}$.

El caso, conocido por todos, viene motivado por el despido de un trabajador tras su negativa a participar en una muestra de un producto (jamón ibérico) ante los medios de comunicación y las autoridades autonómicas extremeñas de la Consejería de Agricultura, para la presentación de la denominación de origen del jamón de bellota producido por la empresa en la que

${ }^{37}$ F. P. Blasco Gascó, «Algunas cuestiones del derecho a la propia imagen», ob. cit., pp. 9 y 10.

${ }^{38}$ Un comentario a esta sentencia puede encontrarse en J. PARDO FALCón, «Los derechos fundamentales como límites de los poderes del empresario (un comentario a las SSTC 99/1998, de 11 de abril, y 6/1995, de 10 de enero)», Revista Española de Derecho Constitucional, 49, 1997.

${ }^{39}$ Hay pronunciamientos anteriores, como la STC 231/1988, de 2 de diciembre, el caso del vídeo de Paquirri, en el que, como se ha visto, el Tribunal Constitucional tan solo efectúa un acercamiento negativo al contenido del derecho a la propia imagen, al considerar que la difusión de imágenes de una persona fallecida no afecta al derecho fundamental a la imagen propia. 
prestaba sus servicios el solicitante de amparo. El recurrente se negó alegando que no deseaba que su imagen fuese captada fotográficamente y la empresa procedió a despedirlo.

El Tribunal Constitucional, teniendo en cuenta que existe un derecho fundamental involucrado, analiza si existe justificación en la orden del empresario que legitime su vulneración.

Como la restricción al derecho fundamental no venía impuesta por la naturaleza del vínculo contractual, no basta con alegar que existe un interés del empresario, sino que hay que acreditar que «no es posible de otra forma alcanzar el legítimo objetivo perseguido, porque no existe medio razonable para lograr del trabajador y el de la organización en que se integra» ${ }^{40}$.

Dado que no se acredita, el Tribunal considera que los tribunales de instancia no han efectuado una correcta ponderación de los derechos en juego y concede el amparo. Este pronunciamiento le da la oportunidad al Tribunal de comenzar a exponer su concepción sobre este derecho fundamental:

«El primer elemento a salvaguardar sería el interés del sujeto en evitar la difusión incondicionada de su aspecto físico, que constituye el primer elemento configurador de su intimidad y de su esfera personal, en cuanto elemento básico de identificación y proyección exterior y factor imprescindible para su reconocimiento como individuo. En este contexto, la captación y difusión de la imagen del sujeto solo será admisible cuando la propia -y previa- conducta de aquel o las circunstancias en que se encuentra inmerso justifiquen el descenso de las barreras de reserva para que prevalezca el interés ajeno o el público que puedan colisionar con aquel» ${ }^{41}$.

A mi juicio, este pronunciamiento constituye uno de los más relevantes de los dedicados al derecho fundamental a la propia imagen, pues en él se observa que el Tribunal Constitucional considera este derecho como un auténtico derecho fundamental, independiente de los derechos a la intimidad y al honor. Esta autonomía resulta esencial para que el derecho pueda desplegar toda su virtualidad garantista en el ámbito de los medios de comunicación, ámbito en el que potencialmente el derecho a la propia imagen resulta más vulnerable.

\section{El derecho a la propia imagen como límite de la actividad de los medios de comunicación}

El ámbito natural de conflicto del derecho a la propia imagen es el que se produce como consecuencia de la actividad de los medios de comunica-

${ }^{40}$ STC 99/1994, de 11 de abril, F.J..$^{\circ}$.
${ }^{41}$ STC 99/1994, de 11 de abril, F.J. 5. 
ción. Gracias a ello contamos con una serie de resoluciones en las que la propia imagen se plantea como límite a la actividad de dichos medios, en línea con lo establecido en el artículo 20.4 CE.

No todos los conflictos que tienen como escenario los medios de comunicación resultan comparables. Se podría distinguir entre aquellas actividades que responden a la libertad de información o de expresión, y aquellas otras propias de la que se ha dado en llamar prensa de entretenimiento, rosa o del corazón. En este ámbito, la actividad de los medios, a pesar de que algunos pronunciamientos jurisprudenciales parecen dar a entender que se enmarcaría en el ámbito de la libertad de expresión, resulta difícilmente protegida por la Constitución ${ }^{42}$.

Este conflicto natural, que, como se ha dicho, refleja el artículo 20.4 CE, también está detrás de la formulación de la L. O. 1/82, de 5 de mayo, de Protección Civil del Derecho al Honor, a la Intimidad Personal y a la Propia Imagen, norma de desarrollo «del principio general de garantía de tales derechos contenidos en el citado artículo 18.1», según reza la propia Exposición de Motivos. «En el texto de la Ley Orgánica se percibe una referencia constante a la actividad informativa y, en particular, a los conflictos que suelen plantearse entre los derechos de la personalidad y el ejercicio del derecho a la información» ${ }^{43}$.

Esta norma, que a mi juicio adolece de grandes deficiencias técnicas, recoge un catálogo de conductas consideradas ilegítimas por atentar contra los derechos fundamentales que regula: honor, intimidad y propia imagen. Al hilo de esto, contiene en su artículo 8 una excepción general en su apartado 1: «No se reputará, con carácter general, intromisiones ilegítimas las actuaciones autorizadas o acordadas por la Autoridad competente de acuerdo con la Ley, ni cuanto predomine un interés histórico, científico o cultural relevante».

El apartado 2, que es el que a nosotros nos interesa, se dedica específicamente al derecho a la propia imagen, destacando que «en particular, el derecho a la propia imagen no impedirá su captación, reproducción o publicación por cualquier medio cuando se trate de personas que ejerzan un cargo público o una profesión de notoriedad o proyección pública y la imagen se capte durante un acto público o en lugares abiertos al público. La utilización de la caricatura de dichas personas, de acuerdo con el uso social. La

${ }^{42}$ De hecho, entre nosotros, y a diferencia de lo que ha sucedido en otros países como Alemania, el Tribunal Constitucional ha negado la cobertura constitucional de la llamada prensa de entretenimiento, destacando que no puede confundirse la relevancia pública de una información con su carácter noticioso (STC 134/1999, de 15 de julio, entre otras). Sobre este particular puede consultarse M. MEDINA GUERRERO, La protección constitucional de la intimidad frente a los medios de comunicación, Valencia, Tirant lo Blanch, 2008, p. 155 y ss.

${ }^{43}$ A. Azurmendi AdÁrraga, ob. cit., p. 210. 
información gráfica sobre un suceso o acaecimiento público cuando la imagen de una determinada persona aparezca como meramente accesoria. Las excepciones contempladas en los párrafos a) y b) no serán de aplicación respecto de las autoridades o personas que desempeñan funciones que por su naturaleza necesiten el anonimato de la persona que las ejerza».

Como ha sostenido Pascual Medrano, la L. O. en su artículo 8.2 trata de acotar las relaciones del derecho a la propia imagen y las libertades del artículo $20 \mathrm{y}$, a tal efecto, establece tres límites concretos al primero ${ }^{44}$. Sin embargo, como ha puesto de manifiesto la doctrina, la manera de hacerlo no es la más apropiada, pues la dicción literal permite acoger excepciones que no están guiadas por ese interés informativo ${ }^{45}$.

Los límites en cuestión hacen referencia al carácter de personaje público de la persona retratada, a las caricaturas de esas mismas personas y a la imagen que se ofrece como accesoria de una información sobre un suceso o acaecimiento público. El Tribunal Constitucional ha procedido a delimitar las tres excepciones aunque en ámbitos diversos. Muy interesante resulta, a mi juicio, cómo el Tribunal Constitucional ha corregido la aplicación que los tribunales ordinarios, en concreto, el Tribunal Supremo, venían efectuando de la excepción relativa a los «personajes públicos», con motivo de publicaciones que en vez de responder al ejercicio de la libertad de información eran producidas al amparo de la prensa de entretenimiento ${ }^{46}$.

En el caso de las caricaturas, su análisis desde la perspectiva de la propia imagen se ha producido también en el mismo ámbito, incluyéndose en el concepto los fotomontajes.

Como los supuestos no son parangonables, vamos a proceder a un análisis diferenciado de la jurisprudencia constitucional en función de que nos hallemos en el plano de la prensa de entretenimiento o se trate del ejercicio de las libertades comunicativas del art. 20 CE. Obviamente, estas diferencias suponen una toma de postura a favor de la irrelevancia constitucional o, lo que es lo mismo, la falta de cobertura constitucional de la prensa de entretenimiento. Difícilmente, si atendemos a la concepción del Tribunal Constitu-

${ }^{44}$ A. Pascual Medrano, El derecho fundamental a la propia imagen, ob. cit., 132. En el mismo sentido se pronuncia RoYo JARA, que ha destacado que aunque no se hace referencia expresa a la información, es lo que gravita sobre todo el precepto. J. RoYo JARA, La protección del derecho a la propia imagen, Madrid, Colex, 1987, p. 163.

${ }^{45}$ Para IgARTUA ARREgui la postura de la norma es errónea porque «desconoce que, a pesar de que se den las circunstancias del precepto (p. ej., persona pública en lugar público), puede no existir interés público en la divulgación de esa imagen», F. IGARTUA ARREGUI, La apreciación comercial de la imagen y del nombre ajenos, Madrid, Tecnos, 1991, pp. 118 y 119.

${ }^{46}$ Sentencias del Tribunal Supremo de 17 de diciembre de 1997 (caso Alberto Alcocer I) y de 14 de noviembre de 2002 (caso Alberto Alcocer II); Sentencia del Tribunal Supremo de 21 de octubre de 1997 (caso Alberto Cortina). 
cional sobre la libertad de expresión puede considerarse que la prensa rosa entraña un ejercicio de esta ${ }^{47}$.

\section{IV.1. Propia imagen y prensa de entretenimiento}

La intensa conflictividad judicial motivada por la prensa de entretenimiento, si bien muestra que existen problemas no resueltos en el ámbito de los derechos de la personalidad, que no siempre parecen capaces de limitar la actividad de la prensa rosa, ha permitido al Tribunal Constitucional desarrollar su concepción más acabada sobre este derecho fundamental, por dos vías. La primera, afirmando la naturaleza bifronte del derecho a la propia imagen mediante el reconocimiento de una faceta que podríamos denominar patrimonial junto a la constitucional o moral del derecho. Esto ha posibilitado el pronunciamiento sobre determinados aspectos que, a juicio del Tribunal Constitucional, no podían ser incluidos en la esfera constitucional, lo que nos ofrece un acercamiento al derecho fundamental desde una perspectiva negativa o de exclusión. En este sentido y, como se analizó supra, el Tribunal Constitucional se ha pronunciado acerca de la revocabilidad del consentimiento, que en líneas generales cabría considerar al margen del derecho fundamental a la propia imagen, sobre la imagen de un personaje de ficción y sobre la difusión de la imagen de personas fallecidas.

La segunda, a través de la reinterpretación de algunas de las excepciones previstas en el art. 8.2 de la L. O. 1/82, de 5 de mayo, a las que se les ha conferido un alcance diverso que el otorgado por los tribunales ordinarios. Veámoslo con detenimiento.

\section{A) Personajes PÚblicos y PROPIA IMAgen}

Como se ha destacado, el art. 8.2 de la L.O. 1/82, de 5 de mayo, señala que el derecho a la propia imagen no impedirá «su captación, reproducción o publicación por cualquier medio cuando se trate de personas que ejerzan un cargo público o una profesión de notoriedad o proyección pública y la imagen se capte durante un acto público o en lugares abiertos al público». En esta excepción se conjugan algunos elementos que conviene precisar.

El primero, el ámbito subjetivo de la excepción. Por personaje público hay que entender, siguiendo al Tribunal Constitucional a «quienes tienen

47 «Procede señalar que el valor preponderante de las libertades públicas del art. 20 de la Constitución, en cuanto se asienta en la función que estas tienen de garantía de una opinión pública libre indispensable para la efectiva realización del pluralismo político, solamente puede ser protegido cuando las libertades se ejerciten en conexión con asuntos que son de interés general por las materias a que se refieren y por las personas que en ellos intervienen y contribuyan, en consecuencia, a la formación de la opinión pública» (STC 107/1988, de FJ de 25 de junio, FJ 2. ${ }^{\circ}$ ). 
atribuida la administración del poder público» ${ }^{48}$. Por su parte, las personas que ejercen una profesión de notoriedad o proyección pública son «aquellas personas que alcanzan cierta publicidad por la actividad profesional que desarrollan o por difundir habitualmente hechos y acontecimientos de su vida privada, o que adquieren un protagonismo circunstancial al verse implicados en hechos que son los que gozan de relevancia pública ${ }^{49}$. Esta definición de la ambigua categoría de personajes públicos ha sido criticada por la doctrina, por su excesiva amplitud ${ }^{50}$.

Según la dicción del artículo 8.2, las personas así consideradas, al parecer, pierden su derecho a la propia imagen cuando se encuentran en actos públicos o en lugares abiertos al público. En el primer caso, la cuestión parece clara: en actos públicos el derecho fundamental a la propia imagen cede a favor del carácter público del acto en sí. Ciertamente, tiene sentido que personas que ejerzan un cargo público o una profesión de notoriedad o proyección pública tengan que ver como su imagen resulta captada y difundida en actos públicos. Sería absurdo tener que requerir el consentimiento de los políticos asistentes a un mitin, de actores en la presentación de una película o de los futbolistas que disputan un partido.

En estos casos, como decía, no solo cede este derecho fundamental, sino que también el derecho a la intimidad sufre recortes en su ámbito de protección. Por ejemplo, si en un acto oficial dos cargos públicos mantienen una actitud afectiva, difícilmente podrán argumentar su derecho a la intimidad para impedir la difusión de las imágenes. El carácter público del acto prevalece sobre su eventual derecho, al menos en este caso. Lo mismo podría afirmarse del derecho al honor y el nivel de crítica que determinadas personas, en función de su cargo, tienen que soportar.

El Tribunal Constitucional ha admitido expresamente la necesidad de modular el contenido de los derechos reconocidos en el artículo 18.1 CE, cuando el titular es un personaje público:

«Los personajes públicos o dedicados a actividades que persiguen notoriedad pública aceptan voluntariamente el riesgo de que sus derechos subjetivos de personalidad resulten afectados por críticas, opiniones o revelaciones adversas y, por tanto, el derecho de información alcanza, en relación con ellos, su máximo nivel de eficacia legitimadora, en cuanto que su vida y conducta moral participan del interés general con una mayor intensidad que la de aquellas personas privadas que, sin vocación de proyección pública, se ven circunstancialmente involucradas en asuntos de trascendencia pública, a las cuales hay que, por consiguiente, reconocer un

${ }^{48}$ STC 192/1999, de 15 de julio, F.J. 7. ${ }^{\circ}$

${ }^{49}$ STC 99/2002, de 6 de mayo, F.J. 7. ${ }^{\circ}$.

50 M. Medina Guerrero, La protección constitucional de la intimidad frente a los medios de comunicación, ob. cit., p. 146 y ss. 
ámbito superior de privacidad, que impide conceder trascendencia general a hechos o conductas que la tendrían de ser referidos a personajes públi$\cos \gg 51$.

Sin embargo, una cosa es admitir esta modulación y otra muy distinta considerar que la inclusión del titular en la ambigua categoría de personaje público constituye una patente de corso para difundir cuantas informaciones e imágenes se considere oportuno. Además, si se atiende al texto de la sentencia, el Tribunal Constitucional alude al ejercicio del derecho de la información, lo que modifica sustancialmente las cosas ${ }^{52}$.

Pero lo cierto es que, atendiendo al precepto legal, las personas que desempeñan un cargo público o una profesión con proyección o notoriedad pública ven recortado su derecho a la propia imagen, hasta el punto de que en los lugares abiertos al público no disfrutan de él. Qué duda cabe de que el necesario respeto al contenido esencial del derecho fundamental no soporta tal restricción, que entraña circunscribir el disfrute del derecho para toda una categoría de personas únicamente a su ejercicio en lugares no abiertos al público.

La óptica adecuada para interpretar correctamente este precepto legal parte del concepto de «relevancia pública» y de la necesaria ponderación con las libertades de información y expresión del que el derecho a la propia imagen, como el honor y la intimidad, es un límite preciso según reza el artículo $20.4 \mathrm{CE}^{53}$. En lugares abiertos al público, el personaje público gozará de derecho a la propia imagen. Lo que sucede es que es posible, solo posible, que este derecho tenga que ceder si se emite una información de relevancia pública o se trata de un acto público, como el mitin, la presentación de una película o el partido de fútbol. En otro caso, el derecho a la propia imagen debe prevalecer.

${ }^{51}$ STC 171/1990, de 12 de noviembre, F.J. 5. ${ }^{\circ}$

${ }^{52}$ En el ámbito del derecho a la información, la categoría de personaje público guarda relación con el concepto de relevancia pública, de manera que, en ocasiones, un hecho que de por sí no es relevante, puede convertirse en tal por la persona que lo protagoniza. Por ejemplo, que un ciudadano anónimo incurra en una infracción del código de circulación difícilmente podría ser considerado de relevancia pública. Si el que la comete es el Director General de Tráfico, sí.

${ }^{53}$ De interés informativo habla AzURMENDI ADÁRRAGA, que destaca que «para evitar posibles abusos del empleo de la imagen ajena, y que el derecho a la propia imagen quede desvirtuado, es necesario, en primer lugar, el establecimiento de una noción común de interés informativo, al que atiendan todos los que participan en los procesos de comunicación pública y, después, la fijación del núcleo esencial del derecho a la propia imagen. De forma que la labor del juzgador en los casos en los que el interés informativo tenga dudosa sustantividad, se pueden hacer valer las prerrogativas del titular de la imagen». A. AzURMENDI ADÁRRAGA, El derecho a la propia imagen: su identidad y aproximación al derecho a la información, ob. cit, p. 213. 
Lo mismo sucederá en lugares no abiertos al público, donde la única diferencia estriba en sostener que, presumiblemente, lo que sucede al resguardo del público podría con más probabilidad pertenecer a la esfera de lo íntimo. Sin embargo, el ámbito protegido por el derecho a la intimidad no guarda una relación directa con el emplazamiento físico en el que se desarrolla la actividad del titular, aun cuando este tenga una notable influencia ${ }^{54}$.

Si bien esa referencia podría guardar alguna relación con el derecho a la intimidad, en ningún caso se encuentra su pertinencia en relación con la propia imagen. Como se ha visto, mientras que no existen problemas en reconocer que durante los actos públicos, sus intervinientes ven como su derecho a la propia imagen sufre una restricción, en aras del carácter público del acto en sí, la referencia a «lugares abiertos al público» no tiene razón de ser.

Este precepto, literalmente interpretado, ofrece cobertura suficiente para algunas resoluciones del Tribunal Supremo, muy discutibles, que han sido corregidas en sede de amparo constitucional, por violación, precisamente, del derecho a la propia imagen. En este sentido, el Tribunal Supremo ha llegado a considerar que la publicación de fotografías tomadas en una reserva federal de caza ${ }^{55} \mathrm{o}$ una playa ${ }^{56}$, en tanto que lugares abiertos al público y en concurrencia con el carácter también público de las personas retratadas, constituía base suficiente para considerar que las conductas recurridas no suponían intromisiones ilegítimas en el derecho a la propia imagen ${ }^{57}$.

En la STC 139/2001, de 18 de junio, se resuelve el recurso de amparo interpuesto por Alberto Cortina de Alcocer por la publicación de unas fotografías del demandante acompañado de Marta Chávarri Figueroa, sin el consentimiento de los protagonistas, que habían sido tomadas en un viaje a Kenia. Para el Tribunal Supremo, en este supuesto era de aplicación la excepción prevista en el artículo 8.2.a de la L. O. 1/82, de 5 de mayo, dado que el Sr. Cortina era una persona muy conocida en el ámbito financiero y social en general y una reserva de caza en Kenia es un ámbito abierto al público. El Tribunal Constitucional, por su parte, considera lesionado el derecho a la propia imagen del recurrente y para ello se centra en la naturaleza de las fotografías: «queda evidenciado dicho carácter personal, privado

\footnotetext{
${ }^{54}$ Sobre el derecho a la intimidad puede consultarse C. RuIz Miguel, La configuración constitucional del derecho a la intimidad, ob. cit. Asimismo, P. L. Murillo DE LA Cueva, «El derecho a la intimidad», ob. cit.

${ }^{55}$ STC 139/2001, de 18 de junio.

${ }^{56}$ STC 83/2002, de 22 de abril.

${ }^{57}$ Un comentario a estas dos sentencias puede encontrarse en A. DE LA IgLESIA ChAMARRO, «El derecho a la propia imagen de los personajes públicos. Algunas reflexiones a propósito de las SSTC 139/2001 (caso Cortina) y 83/2002 (caso Alcocer)», Revista Española de Derecho Constitucional, 67, 2003.
} 
y reservado de las expresadas fotografías, cualesquiera que fueran las personas a las que reproducían y el lugar en que se hubieran hecho» ${ }^{58}$.

La afirmación del Tribunal es lo suficientemente expresiva de la escasa relevancia que el lugar o el carácter de personaje público del protagonista tiene en casos como este, en el que la fotografía no hace más que reproducir momentos de la vida privada del titular. Privada que, como el mismo órgano de garantía se encarga de precisar, no quiere decir íntima: «No es preciso examinar si tal documento se halla en el ámbito propio de la intimidad, puesto que ni en la demanda de amparo se invoca expresamente el derecho a la intimidad ni, por otra parte, se condicionan mutuamente, de modo necesario, este derecho y el de la propia imagen, dada la autonomía de uno y otro, por más que puedan estar vinculados en algunos supuestos» ${ }^{59}$. En este caso, también influye notablemente el hecho de que las fotografías tuvieran una procedencia ilícita ${ }^{60}$.

La STC 83/2002, de 22 de abril, resuelve el recurso de amparo interpuesto por Alberto de Alcocer Torra, por la publicación de unas fotografías tomadas en una playa en compañía de una mujer en una clara actitud de afectividad. Entre los diversos argumentos que llevan al Tribunal Supremo a denegar sus pretensiones, algunos tan increíbles como que la publicación de las fotografías responde al ejercicio de la libertad de información o que los usos personales del recurrente y los usos sociales en general eliminan el concepto de intromisión en la intimidad, se alude, en relación con la lesión al derecho a la propia imagen, a la excepción del artículo 8.2.a de la L. O. 1/82, de 5 de mayo, al considerar que el recurrente es una persona de proyección pública, que se da un interés general de la información y que la imagen se tomó en una playa, un lugar abierto al público. El Tribunal Constitucional rechaza esta argumentación, al igual que ya había hecho en la STC 139/2001, de 18 de junio y basándose en los mismos argumentos: carácter personal y reservado de las fotografías y procedencia ilícita de estas.

Como se aprecia en los casos referidos, el Tribunal Constitucional no ha encontrado óbice alguno para declarar lesivas de la propia imagen la publicación de unas fotografías, aun cuando los protagonistas, o al menos uno de ellos, eran personas conocidas en el mundo financiero y el lugar de captación de las fotos era un lugar abierto al público. Obviamente, aquí el Tribunal ha tenido en cuenta no solo el carácter abierto o no al público del lugar donde se toman las fotografías, sino la relevancia pública de la información, que era inexistente. Aunque el Tribunal Constitucional no razona desde la perspecti-

${ }^{58}$ STC 139/2001, de 18 de junio, F.J. 5. ${ }^{\circ}$.

${ }^{59}$ Ibídem.

${ }^{60}$ En el mismo sentido, A. De la IGLesia Chamarro, «El derecho a la propia imagen de los personajes públicos. Algunas reflexiones a propósito de las SSTC 139/2001 (caso Cortina) y 83/2002 (caso Alcocer)», ob. cit. 
va de la libertad de información, dado que el contenido de la publicación no podía ampararse en su ejercicio, la vulneración del derecho a la propia imagen se declara en aras precisamente de ese carácter privado, reservado y personal de las fotografías en cuestión.

Entre nosotros, el problema deriva, como se ha dicho, de la dicción literal del artículo 8.2 de la L. O. 1/82, de 5 de mayo, que en su interpretación gramatical supone privar a los personajes públicos del derecho a la propia imagen siempre que se encuentren en lugares públicos. Sin embargo, como ha puesto de relieve Pascual Medrano, existe la «necesidad de verificar la existencia de interés público informativo, aun cuando se trate de personas públicas y la imagen sea captada en un lugar abierto al público» ${ }^{61}$.

\section{B) LAS CARICATURAS, DE ACUERDO CON EL USO SOCIAL}

El más reciente pronunciamiento del Tribunal Constitucional sobre el derecho a la propia imagen, la STC 23/2010, de 7 de abril, resuelve un recurso de amparo en el que se dilucida la vulneración del derecho a la propia imagen por un fotomontaje en el que se sobrepone sobre un cuerpo desnudo la imagen del rostro de una persona muy conocida en el mundo de la prensa del corazón. El citado fotomontaje había provocado una condena a la revista por parte de los tribunales de instancia, que recurre en amparo alegando vulneración de su derecho a la libertad de expresión.

Para el Tribunal Constitucional, la publicación que origina el conflicto es una composición con una finalidad humorística mediante la manipulación de la imagen, por lo que puede calificarse de caricatura, en tanto que «creación satírica realizada a partir de las facciones y el aspecto de alguien, deformando su realidad».

Tras destacar que el uso de las caricaturas puede responder a un legítimo ejercicio de la libertad de expresión, en cuanto «contribuya al mantenimiento de una opinión pública crítica y plural, como "condición previa y necesaria para el ejercicio de otros derechos inherentes al sistema democrático" (STC 159/1986, de 16 de diciembre, FJ 6; 77/2009, de 23 de marzo, FJ4)» ${ }^{62}$, constata que la caricatura en cuestión no respondía a un legítimo ejercicio de la libertad de expresión ni a ningún otro fin que justificara la intromisión en el derecho a la propia imagen y, en consecuencia, deniega el recurso de amparo. En sus palabras, «del examen de las circunstancias del caso se desprende que la empresa recurrente en amparo, lejos de realizar un ejercicio legítimo de su libertad de expresión, vulneró el derecho a la propia imagen de doña Isabel Iglesias al publicar sin su consentimiento el montaje caricaturesco que había elaborado mediante la manipulación de su fotografía ${ }^{63}$.

\footnotetext{
${ }^{61}$ A. Pascual Medrano, El derecho fundamental a la propia imagen, ob. cit., p. 143.

${ }^{62}$ STC 23/2010, de 7 de abril, F.J. 5. ${ }^{\circ}$.

${ }^{63}$ Ibídem.
} 
De esta manera, si bien queda claro que el uso de las caricaturas de los personajes públicos de acuerdo con el uso social puede constituir un ejercicio legítimo de la libertad de expresión, no siempre es así, de manera que el uso de la caricatura de un personaje público no excluye de manera automática la lesión del derecho a la propia imagen. Habrá que analizar caso por caso si la caricatura responde al ejercicio legítimo de las libertades comunicativas y, si así es, se excepciona la aplicación del derecho a la propia imagen del caricaturizado.

Por tanto, el Tribunal Constitucional nos ofrece una auténtica relectura de las excepciones previstas en la L. O. 1/82, de 5 de mayo, cuando nos situamos en el ámbito de la prensa de entretenimiento. Esta reinterpretación tiene razón de ser porque en estos casos no podemos alegar que nos encontramos en el ámbito de la ponderación de derechos, pues nada habría que ponderar. Todo lo contrario. Difícilmente en los casos que se han reseñado existe un fundamento que pueda esgrimirse como límite a un derecho fundamental como el de la propia imagen. Distintas son las cosas cuando nos situamos en el ámbito de la libertad de información o expresión.

\section{IV.2. Propia imagen y libertad de información}

Como ya se ha puesto de manifiesto, existen dudas más que fundadas para considerar que la llamada prensa de entretenimiento goza de cobertura constitucional o, al menos, de una cobertura suficiente que justifique la vulneración de derechos fundamentales reconocidos en el art 18.1 CE.

La situación es totalmente diversa cuando nos situamos en el ámbito de la libertad de información. La relevancia pública constituye el elemento fundamental que puede determinar que la imagen que acompaña a una determinada información no vulnere el derecho fundamental a la propia imagen del efigiado. A esta idea parece responder el artículo 8.2.c cuando excepciona del catálogo de intromisiones ilegítimas la información gráfica sobre un suceso o acaecimiento público cuando la imagen de una persona determinada aparezca como meramente accesoria.

Como puede constatarse de manera inmediata, este precepto se articula sobre dos coordenadas de gran ambigüedad: suceso o acontecimiento público e imagen accesoria ${ }^{64}$.

El precepto parece aludir al derecho a la propia imagen de personas anónimas que, de manera incidental, aparecen en una información sobre un suceso o acaecimiento de relevancia. Por otro lado, también podría incluirse aquí la información gráfica sobre personas que, por su relación con un determinado asunto, adquieren relevancia pública.

${ }^{64}$ J. RoYo JARA, La protección del derecho a la propia imagen, ob. cit., p. 171. 
En la jurisprudencia del Tribunal Constitucional se aprecia que la resolución de los supuestos de lesión del derecho a la propia imagen que apoya una información tiene mucho que ver con el juicio que merezca la información en sí.

En la STC 132/1995, de 11 de septiembre, se analiza la regularidad constitucional de una información relativa al procesamiento de dos magistrados por el Tribunal Supremo, desde la perspectiva de los derechos al honor y la propia imagen. En el texto se ofrece información sobre el procesamiento de dos magistrados por delitos cometidos en el ejercicio de su cargo. Se acompaña de una fotografía de los dos procesados en pose amistosa tras una fiesta desarrollada en la plaza de toros privada de uno de los retratados.

El Tribunal Constitucional, tras dar por buena la interpretación del Supremo que había considerado que la información gozaba de protección constitucional, una vez constatada la relevancia pública y la veracidad, analiza la cuestión desde la perspectiva del derecho fundamental a la propia imagen.

Así, destaca que la fotografía no puede desvincularse de la totalidad de la información, entre cuyos propósitos estaba mostrar la relación existente entre los dos magistrados imputados por el mismo comportamiento delictivo. Además, subraya el Tribunal que «la imagen difundida -que se toma de otro medio de comunicación, por lo que la posible irregularidad de su captación le sería imputable a este otro medio-, es por lo demás altamente inocua, sin que se advierta intención insultante o propósito de mofa, ni en ella ni el breve texto que le sirve de pie» ${ }^{65}$.

Y continúa: «Así englobada en la totalidad de la información (...) no es dudoso que participa de las mismas características de aquella, y que no puede ser objeto de juicio diferenciado del que en general merecen los datos puestos en conocimiento público por el medio de comunicación codemandado en el proceso civil: información referida a persona pública, en asunto de evidente interés general y veraz. Otro caso sería tanto como afirmar que solo la libertad de comunicar información escrita posee un régimen distinto y privilegiado a la que se comunica por medio de la imagen gráfica. No es por ello procedente que demos a la publicación de la fotografía un tratamiento distinto al que merece el conjunto de la información, ni que reiteremos la razón de que, inscribiéndose en el ámbito constitucionalmente protegido de la libertad de información, esta deba prevalecer, en el caso, también el derecho a la propia imagen del recurrente» ${ }^{66}$.

Un tratamiento parecido se observa en el ATC 176/07, de 1 de marzo. En este caso, el conflicto viene planteado por la conocida fotografía del empresario Javier de la Rosa comiéndose un bocadillo en su celda de la cárcel

${ }^{65}$ STC 132/1995, de 11 de septiembre, F.J. 6. ${ }^{\circ}$

${ }^{66}$ Ibídem. 
modelo de Barcelona. El amparo se plantea por el efigiado contra la sentencia del Tribunal Supremo que había estimado que esta no entrañaba vulneración de los derechos del recurrente, al estar amparada por la libertad de información. Parte de la argumentación gira en torno al derecho de la intimidad, sobre la base de si una celda puede considerarse o no domicilio.

Para el Tribunal Constitucional, en este caso nos encontramos ante una fotografía que más que ilustrar una información, la contiene en sí misma: «Lo relevante informativamente es la expresión gráfica del ingreso en prisión del recurrente a raíz de unas actuaciones judiciales que adquirieron gran relevancia pública en su momento» ${ }^{67}$. En este caso, por tanto, el TC aprecia que la fotografía en sí es ejercicio de la libertad de información por lo que debe ceder el derecho a la propia imagen.

En consecuencia, para el Tribunal Constitucional:

«Aplicando este criterio al supuesto actual debemos llegar a la conclusión de que la fotografía era suficientemente noticiosa como para privar a su protagonista de las facultades de control sobre su reproducción gráfica que le atribuye el derecho a la propia imagen. La imagen reproducida, con independencia de que pueda afectar a otros bienes, transmite por sí misma una información relevante cual es el ingreso en prisión de un conocido financiero, por lo que, tal y como concluye la Sentencia del Tribunal Supremo, desde el punto de vista del citado derecho constitucional nada puede reprocharse a su captación y a la utilización que hizo, en esta ocasión, el medio informativo» ${ }^{68}$.

Hasta aquí, creo que nada puede reprocharse a la jurisprudencia del Tribunal Constitucional. En el primer caso, la fotografía ilustra una información veraz y relevante públicamente. En el segundo, la foto constituye en sí misma información, sin que se aprecie lesión de otros derechos fundamentales.

Realmente, estos casos no se enmarcarían en la excepción prevista en el artículo 8.2.c, que parece estar pensada para ciudadanos anónimos que de manera fortuita aparecen retratados o filmados como consecuencia de su participación en un suceso o acontecimiento público. Sería el caso, por ejemplo, del asistente a un partido de fútbol o una manifestación que aparece retratado en el periódico, de una manera destacada, o su imagen captada y luego difundida en televisión.

En los casos referidos, por el contrario, aunque la imagen pueda tildarse de accesoria en el primer supuesto, pues ilustra la información y de información propiamente dicha en el segundo, es la relevancia pública de lo que se transmite lo que a priori justificaría la lesión en el derecho a la propia imagen, que cede ante un ejercicio legítimo de la libertad de información.

${ }^{67}$ ATC 176/2007, de 1 de marzo, F.J. 2..

${ }^{68}$ Ibídem. 
Más dudas se plantean en relación con el supuesto resuelto por la STC 72/2007, de 16 de abril, en la que se cuestiona la publicación de una fotografía de una policía municipal tomada en el curso de un desalojo, acompañando a la información que da cuenta de este. La foto en cuestión, que aparece en portada, se toma durante una actuación de la policía municipal de Madrid en auxilio a una comisión judicial para el desalojo de determinadas viviendas. En la foto, la demandante aparece en primer plano y con el rostro perfectamente visible, vestida con su uniforme oficial y en actitud de inmovilizar y detener a una persona en el suelo. El amparo se dirige frente a la sentencia del Tribunal Supremo que había aceptado la versión del medio de comunicación, en contra de las sentencias previas, que habían dado la razón a la recurrente, la policía retratada.

El Tribunal Constitucional reconoce que la fotografía reproduce de forma nítida el rostro de la demandante y que se produjo sin su consentimiento. Sin embargo, le preocupa más destacar que este derecho fundamental, como todos, no es absoluto o incondicionado, sino que pueden existir circunstancias que lo hagan ceder a favor de otros derechos o intereses legítimos.

En este caso, siguiendo la argumentación de la sentencia, la fotografía reproduce la imagen de una persona en el ejercicio de un cargo público, captada, además, con motivo de un acto público, por lo que para el Tribunal no resulta irrazonable concluir que concurre el supuesto previsto en el primer inciso del art. 8.2.a de la Ley Orgánica 1/82, de 5 de mayo.

Por otro lado, resulta incuestionable para el órgano de garantía constitucional que la información que se transmite es veraz y tiene trascendencia pública. El Tribunal argumenta, además, que la fotografía tiene carácter accesorio respecto de la información publicada y muestra a la demandante en el estricto cumplimiento de su deber, por lo que también concluiría el supuesto del artículo 8.2.c de la citada ley orgánica (información gráfica sobre un suceso o acaecimiento público cuando la imagen de una persona determinada aparezca como meramente accesoria).

En mi opinión, sin embargo, el carácter accesorio de la imagen puede ponerse en cuestión en este caso, en el que hablamos de una policía municipal que participa en un desalojo y aparece retratada en un primer plano, con el rostro perfectamente reconocible, en una situación en la que está cumpliendo con su deber.

Esta circunstancia, lejos de resultar justificativa de la lesión del derecho a la propia imagen, redundaría en la solución contraria. Ciertamente, la relevancia pública del hecho en sí, un desalojo violento decretado por un tribunal, no justifica la publicación de la imagen de una de las participantes fortuitas en el hecho, en un primer plano y con su rostro plenamente visible y en consecuencia, reconocible. Creo que en este caso no puede predicarse la accesoriedad de la imagen. La fotografía, con un primer plano de la recurrente, convierte a la policía en protagonista de la noticia. 
Lo más llamativo, a mi juicio, es la preocupación del Tribunal por incardinar el caso concreto que analiza en los supuestos tasados de la L.O. 1/82, de 5 de mayo, norma a la que, como se ha visto, el Tribunal no siempre se ha sentido vinculado ${ }^{69}$.

A mi juicio, lo más sorprendente de la sentencia no es este uso interesado de la citada ley orgánica, sino la renuncia expresa a efectuar un juicio de proporcionalidad. En este sentido, el Tribunal Constitucional afirma que «aunque es cierto que la utilización de cualquier técnica de distorsión u ocultamiento del rostro de la demandante habría posibilitado que la noticia del desalojo violento hubiera llegado a los lectores de igual manera y sin merma alguna, como se sostiene en la demanda de amparo, no lo es menos que, tal como se afirma en la Sentencia recurrida en amparo, no estamos ante un caso concreto que exija al anonimato, sin perjuicio de que en otros pudiera exigirlo [último inciso del art. 8.2.c de la Ley Orgánica 1/1982, de 5 de mayo]. En efecto, en contra de lo que se aduce por la demandante de amparo, no cabe apreciar que, en las circunstancias de este caso, existan razones de seguridad para ocultar el rostro de un funcionario policial por el mero hecho de intervenir, en el legítimo ejercicio de sus funciones profesionales, en una actuación de auxilio de una comisión judicial encargada de ejecutar una orden de desalojo, ante la decidida resistencia de los ciudadanos afectados» ${ }^{70}$.

Es decir, el Tribunal Constitucional, con esta manera de proceder, está descartando el recurso al principio de proporcionalidad. Así, se reconoce que el juicio de necesidad no se cumple, dado que se afirma que se podría haber acudido a técnicas de distorsión de la imagen y la información no habría mermado.

Conviene calibrar las consecuencias de esta decisión. Creo que podemos afirmar que, en el caso de imágenes que acompañan a una información legítima desde el punto de vista constitucional, el Tribunal Constitucional opta por la prevalencia de la libertad de información sin realizar ni siquiera un juicio de proporcionalidad. Conviene reparar en este dato porque no es lo mismo efectuar un análisis ponderando ambos derechos, aun cuando se otorgue prevalencia a uno de ellos, que no llegar tan siquiera a efectuar dicho juicio. El ejercicio legítimo de la libertad de información parece impedir cualquier intento de análisis de la cuestión desde la perspectiva del conflicto entre

${ }^{69}$ Como ha puesto de manifiesto PARDo FALCón, refiriéndose a la citada ley, el Tribunal Constitucional «no se ha sentido especialmente vinculado por sus concretos postulados a la hora de proceder a la interpretación constitucional de estos derechos», de manera que, como se ha visto, en los casos en que no se ha constatado el referido interés informativo, la excepción no se ha apreciado. J. PARdo FAlCón, «Artículo 18.1», en M. E. CASAS BAAmOnde, Rodríguez-PiÑERo y M. Bravo-Ferrer, (dirs.), Comentarios a la Constitución Española, XXX Aniversario, Madrid, Fundación Wolters Kluwer, 2009, p. 415.

${ }^{70}$ STC $72 / 2007$, de 16 de abril, F.J. 5. ${ }^{\circ}$. 
derechos. De esta manera, creo que, en el caso de una fotografía accesoria a una información de relevancia pública y veraz, no se entra a analizar la cuestión desde la perspectiva de la ponderación de los intereses en juego, sino que prima el ejercicio legítimo del derecho comunicativo. Al menos, cuando el derecho a la propia imagen es el único derecho involucrado. De haberse efectuado ese juicio, a mi modo de ver, la solución del caso habría sido otra.

Distinta suerte se augura en aquellos casos en los que las fotografías que ilustran una información resultan analizadas desde la perspectiva de otro derecho fundamental distinto a la propia imagen ${ }^{71} \mathrm{o}$ existen otros intereses en juego ${ }^{72}$.

En las SSTC 156/2001, de 2 de julio, y 77/2009, de 23 de marzo, se analizan las informaciones vertidas por la revista Interviú en relación con una secta, la secta CEIS, en dos reportajes que se acompañan de fotografías de la recurrente desnuda.

En la STC 156/2001, de 2 de julio, el Tribunal dedica parte de su argumentación a diferenciar los distintos ámbitos protegidos por los derechos a la intimidad y a la propia imagen, y destaca que son derechos independientes, por lo que a través de una fotografía se puede vulnerar el derecho a la propia imagen sin que resulte lesionada la intimidad y a la inversa. Sin embargo y tras realizar una afirmación de este tipo, que se desprende con claridad del art. 18.1 CE, que como hemos visto consagra ambos derechos por separado, se destaca que si a través de una fotografía se vulnera el derecho fundamental a la intimidad, ello supone en sí mismo una vulneración del derecho a la propia imagen. Con lo cual, a mi juicio, hubiera sido más correcto afirmar que la fotografía puede suponer únicamente lesión del derecho a la propia imagen o lesión conjunta de los derechos a la intimidad y a la propia imagen. En este sentido, subraya lo siguiente:

«Si se constata una vulneración del derecho a la intimidad y, al mismo tiempo, una intromisión ilegítima en el derecho a la propia imagen, no será necesario indagar si respecto de estas injerencias existen causas justificativas -relacionadas con la accesoriedad del reportaje respecto de la noticia, el carácter público de la persona afectada, etc.-, ya que la captación y difusión inconsentida de la imagen de una persona que permita su identificación y al mismo tiempo suponga una vulneración de la intimidad personal o familiar, entraña en sí misma una lesión del derecho a la propia imagen ${ }^{73}$.

En este pronunciamiento, el Tribunal convierte la lesión del derecho a la intimidad en el elemento central y, una vez que se considera que este ha

\footnotetext{
${ }^{71}$ SSTC 156/2001, de 2 de julio; 77/2009, de 23 de marzo, y ATC 28/2004, de 6 de febrero.

${ }^{72}$ STC 158/2009, de 29 de junio.

${ }^{73}$ STC 156/2001, de 2 de julio, F.J. 3. ${ }^{\circ}$.
} 
resultado vulnerado, destaca como, además, se lesiona el derecho a la propia imagen: «la declaración de que esas imágenes gráficas han vulnerado su derecho a la intimidad, permite concluir que la intromisión en su derecho a la propia imagen es también una intromisión constitucionalmente ilegítima, sin que para alcanzar esa conclusión sea necesario analizar si concurren otros bienes o derechos -especialmente el derecho alegado de comunicar información- que hipotéticamente pudiesen justificar esa injerencia, ya que al haber declarado que la publicación de las fotografías ha vulnerado el derecho de la intimidad de la recurrente ninguna circunstancia podría legitimar la intromisión en el derecho a la propia imagen que esas mismas fotografías conlleven» ${ }^{74}$.

En un reportaje posterior, la secta sería objeto de tratamiento por la misma revista, que volvería a incluir fotos de la demandante de amparo en el primer caso. En esta ocasión, resuelta por la STC 77/2009, de 23 de marzo, es el medio de comunicación el que recurre en amparo invocando las libertades de información y expresión, toda vez que en sede de la jurisdicción ordinaria se había declarado la lesión del derecho a la propia imagen de algunos de los retratados en el reportaje.

El Tribunal Constitucional reitera su argumentación, y destaca que la publicación de las fotografías de desnudos que se incluyen no está amparada por la libertad de información, y resulta, además, contraria al derecho a la intimidad y a la propia imagen. En este caso, como en el anterior, la lesión del derecho a la intimidad arrastra la del derecho a la propia imagen.

Otro caso significativo es el que da origen al ATC 28/2004, de 6 de febrero, que viene planteado por un diario que había sido condenado por intromisión en la propia imagen por la publicación de una fotografía de una bañista en topless, que resultaba perfectamente reconocible, para ilustrar un reportaje sobre la afluencia de bañistas a una playa recientemente abierta al público.

Un argumento central en la resolución de este caso es, a mi juicio, el hecho de que el medio publicara la fotografía tras manipularla. La original, que era de agencia, mostraba una panorámica de la playa muy concurrida: «la difusión de esta imagen, entresacada de una panorámica general, como sustento de la noticia, en la que lo que aparece es la fotografía de una mujer en topless, no puede afirmarse que sea relevante para conformar la opinión pública en relación con la noticia divulgada (la recuperación de una playa), por lo que negada esta relevancia pública, como premisa del análisis de la posible vulneración del derecho proclamado en el art. 20.1,d) CE, no es preciso analizar ninguna otra cuestión conforme a nuestra doctrina» ${ }^{75}$.

${ }^{74}$ STC 156/2001, de 2 de julio, F.J. 7. ${ }^{\circ}$.

${ }^{75}$ STC 158/2009, de 29 de junio, F.J. 5. ${ }^{\circ}$ 
El elemento fundamental es la falta de correspondencia entre la noticia (la apertura de una playa, con gran afluencia de público) y la fotografía en sí (una sola bañista). Sin embargo, cabe preguntarse qué habría resuelto el Tribunal si la foto no llega a estar manipulada o la persona retratada no fuera una mujer joven en topless. Ciertamente, aunque en el proceso sólo se dilucida la lesión del derecho fundamental a la propia imagen, creo que el hecho de que la retratada se encuentre en topless influye en la resolución final, de la misma manera que influyó en su elección por parte del medio. Sea como fuere, la manipulación de la foto constituye un elemento fundamental en la argumentación del Tribunal.

En la STC 158/2009, de 29 de junio, se resuelve el recurso de amparo interpuesto por un medio de comunicación contra la sentencia que lo condenaba por lesión a la propia imagen con motivo de la publicación de la fotografía de unos niños sin el consentimiento de sus padres. La imagen ilustraba un reportaje sobre niños discapacitados, aunque los niños efectivamente retratados no lo eran.

El Tribunal deniega el amparo, fundamentando su decisión en la falta de accesoriedad de la imagen, atendiendo a su gran tamaño y al protagonismo que cobraban los menores retratados, cuyos rostros ocupaban el centro de la ilustración. En relación con esto, se destaca que «cuando se trata de la representación gráfica de la figura de un menor, la apreciación de la accesoriedad prevista en el referido precepto ha de ser más restrictiva, por la especial protección del derecho a la propia imagen de los menores que establece la Ley Orgánica 1/1996, de 15 de enero, de protección jurídica del menor» ${ }^{76}$.

En consecuencia, el Tribunal termina considerando que «ni existe un interés público en la captación o difusión de la fotografía que pueda considerarse constitucionalmente prevalente al interés superior de preservar la captación o difusión de las imágenes de los menores en los medios de comunicación, ni la veracidad de la información puede justificar esa intromisión ilegítima en el derecho a la propia imagen de los menores, pues este derecho fundamental del menor viene a erigirse, por mor de lo dispuesto en el art. 20.4 CE, en límite infranqueable al ejercicio del derecho a comunicar libremente información veraz» (SSTC 134/1999, de 24 de mayo, FJ 6; y 127/2003, de 30 de junio, FJ 7) ${ }^{77}$.

En este caso, la identificación de los menores no tenía en sí ninguna relevancia. Una imagen de estos, por ejemplo de espaldas, podría haber ilustrado el reportaje de la misma manera. Conviene tener en cuenta que, en el caso de los menores, además de atenernos a su derecho a la propia imagen, el ordenamiento presta especial atención a que no se les identifique aun cuando exista un interés público que lo justifique, si ello puede afectar a su desa-

\footnotetext{
${ }^{76}$ STC 158/2009, de 29 de junio, F.J. 6. ${ }^{\circ}$.

${ }^{77}$ Ibídem.
} 
rrollo posterior ${ }^{78}$. Por ello, con independencia de que el reportaje podía tener un interés informativo, la representación en primer plano de los menores no es aceptada por el Tribunal Constitucional. Además, como se ha visto, existen dificultades para considerar accesoria una imagen que, por su gran tamaño, excede del propio de una mera ilustración de una información relevante. Aunque el Tribunal no lo señale, el hecho de que los niños retratados no sean discapacitados creo que abunda en su posición de no amparar la publicación. Difícilmente puede ilustrar una información sobre niños discapacitados la imagen de unos que no lo son.

En definitiva, la postura del Tribunal Constitucional en el conflicto entre propia imagen y libertad de información es muy clara si la imagen se utiliza para ilustrar una información que goza de los requisitos constitucionales y no vulnera otros derechos fundamentales: la prevalencia de la libertad informativa sobre el derecho personal. En palabras del Tribunal Constitucional:

«Sin duda, el canon de relevancia informativa que se aplica al derecho a la propia imagen ha de ser necesariamente más tenue que el que faculte a una intromisión en los derechos al honor o la intimidad, en la medida en que es también menor la consecuencia lesiva sobre la dignidad que tiene en sí misma la mera reproducción gráfica de la representación externa de una persona. Como dijimos en las SSTC 56/2004 y 57/2004, de 19 de abril, "la imagen enriquece notablemente el contenido del mensaje que se dirige a la formación de una opinión pública libre", de tal manera que si todas las personas cuya imagen aparece reproducida de manera neutral en periódicos o televisiones pudieran exigir una especial trascendencia informativa, la información gráfica se volvería prácticamente imposible, menoscabando el derecho de los ciudadanos a recibir información veraz y el de los periodistas a elaborarla y difundirla ${ }^{79}$.

De esta manera, la intervención de menores de edad modifica el criterio que, de otro modo, se hubiera seguido. Cuestiones como el tamaño de la foto habrían tenido menor incidencia si no se tratara de menores de edad ni de un reportaje sobre discapacitados. Queda claro en esta sentencia que las reglas de juego expuestas rigen las relaciones entre la libertad de información y el derecho fundamental a la propia imagen de los adultos. En el caso de que intervengan menores de edad, la balanza puede inclinarse hacia el lado del derecho a la propia imagen. La propia Constitución avala esta interpretación al consagrar en el artículo 20.4 CE la protección de la juventud y de la infancia como límite adicional a las libertades reconocidas en el art. $20 \mathrm{CE}$, a añadir al conformado por el respeto a los derechos de la personalidad del artículo $18.1 \mathrm{CE}$.

${ }^{78}$ SSTC 134/1999, de 15 de julio, y 127/2003, de 30 de junio.

${ }^{79}$ ATC 176/2007, de 1 de marzo, F.J. 2. ${ }^{\circ}$. 
Pero, con esta salvedad, la consecuencia que habría que extraer es que, en el caso de conflicto entre el derecho a la propia imagen y la libertad de información, esta última primará siempre y cuando la imagen sea realmente accesoria y la información se encuentre protegida constitucionalmente, esto es, cuente con los requisitos constitucionales y no vulnere otros derechos fundamentales. En otro caso, puede ponerse en entredicho el interés público de lo revelado por la imagen, dado que no hay ejercicio legítimo de la libertad de información y puede considerarse que existe lesión del derecho a la propia imagen.

De interés público ha hablado el Tribunal Constitucional en un caso muy curioso, resuelto por la STC 14/2003, de 28 de enero, que da respuesta al recurso de amparo planteado frente a la decisión de la Jefatura Superior de Policía de Valladolid de distribuir una reseña fotográfica, de cuerpo entero, del demandante de amparo, que había sido detenido en el curso de unas investigaciones relacionadas con un homicidio.

Esta fotografía, acompañada con el nombre propio y las iniciales del recurrente, fue distribuida a los medios de comunicación, que la reprodujeron. Frente a los intentos de argumentar desde la perspectiva de la libertad de información del Abogado del Estado y del Ministerio Fiscal, el Tribunal Constitucional rechaza que las Administraciones Públicas o sus órganos sean titulares del derecho a la libertad de información.

Al hilo de sus reflexiones sobre la configuración constitucional del derecho a la propia imagen, destaca que «existen circunstancias que pueden conllevar que la regla enunciada ceda, lo que ocurrirá en los casos en que exista un interés público en la captación o difusión de la imagen y este interés público se considere constitucionalmente prevalente al interés de la persona en evitarlas» ${ }^{80}$.

En este caso, no obstante, se descarta que se trate de un supuesto de conflicto entre derechos fundamentales, por lo que el Tribunal analiza la posible concurrencia de otros bienes constitucionales o de interés público, más dignos de protección, toda vez que la lesión a la propia imagen había quedado constatada por la difusión de una fotografía de cuerpo entero en la que el recurrente era perfectamente reconocible.

Como el Tribunal Constitucional no encuentra esos bienes constitucionales que justifiquen la lesión en el derecho a la propia imagen, concede el amparo por este motivo y destaca además que «ha de configurarse la fotografía cuestionada como un dato de carácter personal del demandante de amparo, obtenida y captada por las fuerzas y cuerpos de seguridad del Estado en el ejercicio de la función constitucional y legalmente conferida a la investigación de los delitos y detención y aseguramiento de sus supuestos autores, y respecto al cual sus miembros están obligados en principio al

${ }^{80}$ STC 14/2003, de 28 de enero, F.J. 5. ${ }^{\circ}$ 
deber del secreto profesional $»^{81}$. Sin embargo, el conflicto no se plantea desde la perspectiva del art. 18.4 CE, protección de datos, por lo que el Tribunal no analiza el caso desde esa óptica ${ }^{82}$.

No podemos saber qué hubiera sucedido si, en vez de recurrirse la decisión de la Jefatura de Policía se hubiera cuestionado la publicación por parte de los medios de comunicación. Los esfuerzos argumentativos del Tribunal dirigidos a destacar que el caso analizado en ningún caso podría estudiarse desde la perspectiva de la libertad de información inducen a pensar que, si así hubiera sido, no se habría considerado lesión del derecho a la propia imagen. Pero son solamente suposiciones.

${ }^{81}$ STC 14/2003, de 28 de enero, F.J. 7..

${ }^{82}$ Un análisis de la imagen desde la perspectiva de la protección de datos puede consultarse en L. Rebollo DelGado, «El derecho a la propia imagen y la imagen como dato», Revista Española de Protección de Datos, 5, 2008. 